\title{
BRIDGING THE GAP BETWEEN PLANNING PROCESS IN MUNICIPALITIES AND LANDSCAPE ARCHITECTURE STUDIES AND RESEARCH IN LATVIA
}

\author{
Natalija N̦ITAVSKA ${ }^{a}$, Daiga ZIGMUNDEb ${ }^{b}$ Madara MARKOVAc, Una İLE ${ }^{d}$ \\ Landscape Architecture and Planning department, Faculty of Environment and Civil Engineering, \\ Latvia University of Agriculture, Rigas street 22, LV-3004, Jelgava, Latvia \\ E-mails: ${ }^{a}$ natalija.nitavska@llu.lv; ${ }^{b}$ daiga.zigmunde@llu.lv; \\ cmadara.markova@llu.lv(correspondingauthor); cuna.ile@llu.lv
}

Received 26 February 2016; accepted 4 October 2016

\begin{abstract}
This article deals with the implementation stages and approaches of the trilateral cooperation "university - student - local government" as well as the benefits and limiting aspects in a real territory planning context. The research summarises the evaluation of the Latvia University of Agriculture (LUA) landscape architecture studies experience in cooperation with 41 municipal and national organisations and 4 unions from Latvia since 2013. Key findings point to the following benefits: the university as a provider of study process obtains a better insight into the topical problems and issues regarding the territorial/territory planning, it has an opportunity to promote the study programmes and the work quality of the future specialists; the greatest benefit for the students is that they can be better prepared for a real work in their chosen profession and they gain experience in real project work which later will be reflected in their CVs; the gain for the local governments is that they have a scientific substantiation for making more appropriate decisions with regard to the further development of the territory, and they have more variants of ideas for a specific territorial development. Restricting factor is time which is determined by the study courses.
\end{abstract}

Keywords: service learning, planning process, work-based studies, territorial development, Institutional University.

\section{Introduction}

An important stage in landscape architecture education is the territory planning of different types and scales, which, already in the study process, develops the future specialists' understanding of the scale of the territory in selecting an appropriate investigation and planning approach (see Benson, Mackenzie 1995; Saura, Martínez-Millán 2001; Wu 2004; e.g. Wu et al. 2002). However, modern scientific publications are showing a trend that landscape architecture studies are becoming increasingly theoretical and comprehensive, focusing more on global issues such as climate change and urbanization. This approach does not allow a student to find a suitable solution in specific situations (see Oles, Horrigan 2015). Developing a project for an actual place with a real customer being interested in developing the territory, encourages the students to think systematically, sometimes even in inter-disciplinary perspective, including critical analysis of pre- viously acquired theoretical knowledge and the use of this knowledge. Students take an active part in the project development process not only in communication with the customer, but also in affecting the progress of the course and project development on the whole (see Grandin et al. 2010). Thus, landscape architecture studies are becoming even more effective.

\section{Different types of teaching/learning aiming at practical use of theoretical knowledge}

Most often the practice-oriented studies are implemented within the framework of work-based and project-based learning (see Deming, Swaffield 2011; Freestone et al. 2006; Genca 2015; Marcia 2008) service learning (see Angotti et al. 2012; e.g. Nelsona et al. 2010; Grabbatina, Fickeya 2012) and practice work (e.g. Wenger-Trayner et al. 2014. The advantage of these methods is emphasized in several scientific articles. Basically the project-based study process 
involves an active participation of students in it. The lectures which are conducted in a traditional way make up the basis of students' theoretical knowledge, while the project-based study activities provide an opportunity to apply this basic knowledge in solving real problem issues, in the development of real territories. In this way linkage is achieved between theory and practice, as well as an understanding of how to use various types of basic knowledge in real life (see Amstrong 1999; e.g. Chinowsky et al. 2006). Although the project-based studies are useful in improving the students knowledge, this approach involves an active participation of teachers in developing cooperation and selection of the territories to be developed. Thus, the limiting factor of the project-based approach in the study process might be the lack of active involvement motivation both from the local government and from the academic staff, since it requires a lot of time and organisational resources.

The students work in their respective field during the study course is a kind of work-based studies (see Williams et al. 2007). This approach is important for the development of professional competencies. An integral part of the study process which is based on the development of practical skills is discussions, exchange of opinions, as well as defending the chosen concepts, being aware of their pros and cons (see Baum 1997). The practical experience of the academic staff plays a great role here, not only to share the experience, but also to be able to most effectively organise the study process and include theory and practice in it in a balanced way, so that these two parts could be linked. As a limiting factor of this approach, one should mention the professional competency of the academic staff required for work-based learning, to be able to ensure the quality monitoring of the study process. Service learning has become a widely used approach in higher education in different fields. It is considered to be an effective tool in increasing the importance of the studies not only for students, but also for people not related to the study process but who are participating in the project development. Consequently, by using the service learning approach in territory planning, the community/society is also involved and educated. Service learning has several potential limitations. One of them can be the problem for the faculty workloads and rewards that directly relate to the motivation mentioned before, the lack of which may be a limiting factor. Another limiting factor can be differing traditions of planning and design. The quality of the design solution is undoubtedly evaluated as a risk factor, since the students are not yet professional designers. In general, it is believed that service learning can offer very useful services to neighbourho- ods while offering students vital skills for working with multiple publices (e.g. Forsyth et al. 2000).

Regarding the practice, it has been assessed that the major winners are the students directly. As the most important benefit for the young professionals is that of working in a team, cooperating with customers; a chance to see how the project is being implemented; feelings of responsibility; developing the culture of work (see Burton 2015).

\section{Different ways of cooperation universities with local government}

Nowadays more often society's participation in territory planning is being emphasized (see Bloemers 2010). In several articles the importance of participation of local governments and communities in the planning process (see Healey 1997), associated with a direct interest in the development of a certain territory has been cooperation in territory planning at different levels is becoming more and more important and the cooperation in territorial planning at various levels, embracing both academic and scientific environment, businesses and municipalities.

The importance of cooperation for developing sustainable development is acknowledged by the development planners, politicians, representatives of society in the form of organisations and unions, as well as researchers (see Zadek et al. 2012). The cooperation with the university gives the municipalities an opportunity to communicate with the inhabitants - through the media or informative reports, reporting on the activities and development plans. The university, in turn, has an opportunity to promote the particular study programme. The article in the newspaper "Zemgales Ziñas" and on the newspaper's home page - "The future LUA landscape architects are helping to tidy up Liktendārzs/ Destiny Garden"; "From Pasta island to Likteñdārzs"; "The students of LUA will develop projects for greenery in Limbaži” (see Zemgales Ziṇas 2013).

Cooperation between university and municipalities can be organised according to different models. In Latvia, service learning is quite widely used by universities by engaging in project development in various sectors of the economy. In Latgale region, tourism development is very important, and the local regional university is actively engaged in it (see Silinevica 2015). Also Dutch universities actively use the university knowledge in development planning, in this case the transfer of knowledge in the social sector (see Postma 2013). The Bulgarian city of Varna has a municipal strategy for cooperation with the institutions of higher education published in 2015, with the goal of developing the city as a student city. The strategy has 
clearly identified benefits from such cooperation (see Varna municipality 2015).

Similar forms of service learning can be realized between the university and businesses, often in association with the municipality (e.g. Nelsona et al. 2010). Cooperation can also be developed between the various levels of educational institutions, promoting a more effective transfer of knowledge. In the Swedish city of Linköping (2014) the educational institutions, including the local university, have developed a joint strategy (Strategy for Cooperation with universities and colleges) (see City of Linköping 2014). Strategy is a good basis for developing cooperation of different types and scale with setting common goals and priorities. This type of cooperation develops more effectively if there is a national strategy to encourage and facilitate the cooperation in various spheres, as for instance, in Norway in 2014, cooperation guidelines between universities and political structures are determined at a national level (see Horizon 2020; ERA 2014).

There is scientific and practical information on institutional cooperation generally, and from it we can identify some major barriers to institutional cooperation:

- Conflicting objectives - partners may bring differing, potentially conflicting objectives. It can be expected that municipalities and university will have different priorities, which will require a collaborative process of discussion and resolution.

- Leadership - lack of appropriate leadership from one of both sides can be a barrier to resolving conflicts and establishing cooperation.

- Alignment of responsibilities and clarity of roles partners can have differing ideas of problems and it could lead to blame shifting and gaps in responsibility between partners.

- Alignment of resources - the financial, human and other resources (e.g. land) that are vital in the implementation the idea of cooperation project.

- Incompatible timing - there may be different timescales for complementary plans e.g. the timing over which municipality would want to have the result is not the same that university can give for students.

- Lack of expertise - municipality can be without experience in terms of what to expect from cooperation with the university. We should also not underestimate the significance of matters of uncertainty, partial knowledge and differing technical approaches in different sectors.

- Lack of transparency - unwillingness to share data or information due to claims of political confidentiality or organisational culture can act to complicate cooperative planning - placing requirements on formal or legal agreements, or consideration of the conditions under which they are collected (see Heckley et al. 2014).

Although cooperation projects between universities and local governments have been described in several publications as it was mentioned before, the main emphasis is on the study process and the benefits for the students from this cooperation. It mainly reflects the development of better understanding about the future profession and necessary knowledge and skills. Thus, the aim of this research was to investigate the benefits and limiting factors of the trilateral cooperation "university - student - municipality", summarising and analysing the experience of such cooperation from the year 2013 within the framework of landscape architecture studies.

\section{Materials and methods}

This publication reflects the key benefits and limiting aspects from the cooperation among the students of the study programme Landscape architecture and planning, teaching staff of the LUA Rural Engineering faculty, 3 non-governmental organisations, 8 municipalities and governmental organisations, 4 unions in Latvia from the year 2013 (Fig. 1) (There are 119 local governments - 110 municipalities and 9 cities in Latvia). At present 20 cooperation agreements have been concluded with local governments/municipalities, but the cooperation exists even with a greater number of local governments/municipalities. Elsewhere in the world the development of cooperation is based on strategies, development of visions and defining of goals.

Latvian law "On Local Governments" (Law "On Local Governments" (19.05.1994 with amendments up to 22.12.2011)) stipulates that local governments are obliged to develop territorial development programmes and to ensure their implementation. It also is associated with such functions as the facilitation for the improvement of the municipal territories, creating parks, squares and green zones as well as determining the land-use policy. Taking into consideration these functions, it is understandable that in order to improve the students' knowledge and experience it is important to cooperate exactly at the municipal level in order to better understand the procedure of planning and design prescribed by law. The Landscape architecture 5-year professional bachelor's programme of Latvia University of Agriculture is composed of study courses which help improve the basic knowledge required for the profession, e.g. drawing skills, sense of space, analysis, planning, etc. To improve this basic knowledge in practice the study courses in Landscape architecture and design are offered. Within the framework of these study courses, the development 


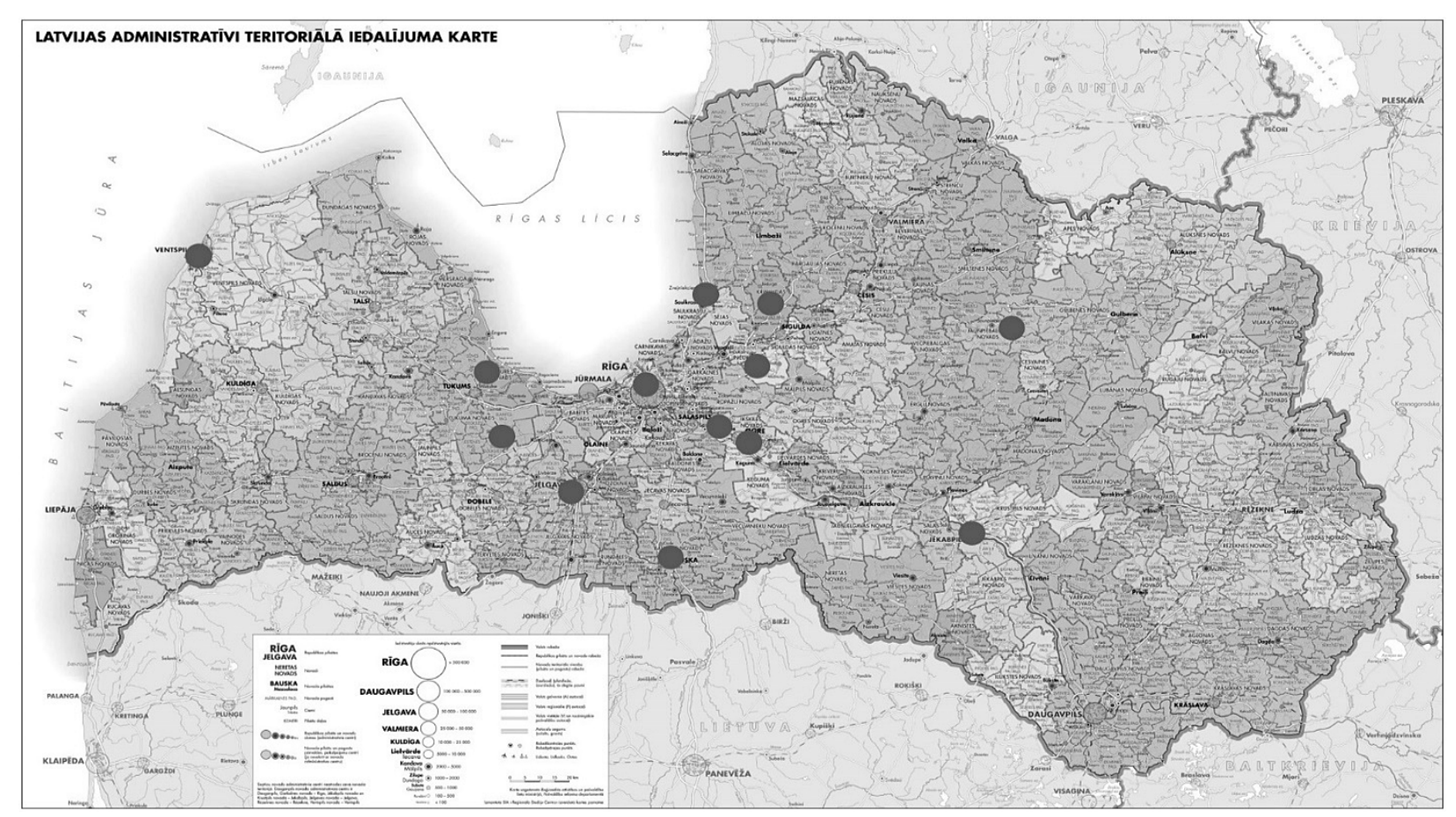

Fig. 1. The map of administrative division of Latvia (modified by authors, http://www.varam.gov.lv/lat/darbibas_veidi/pasv/)

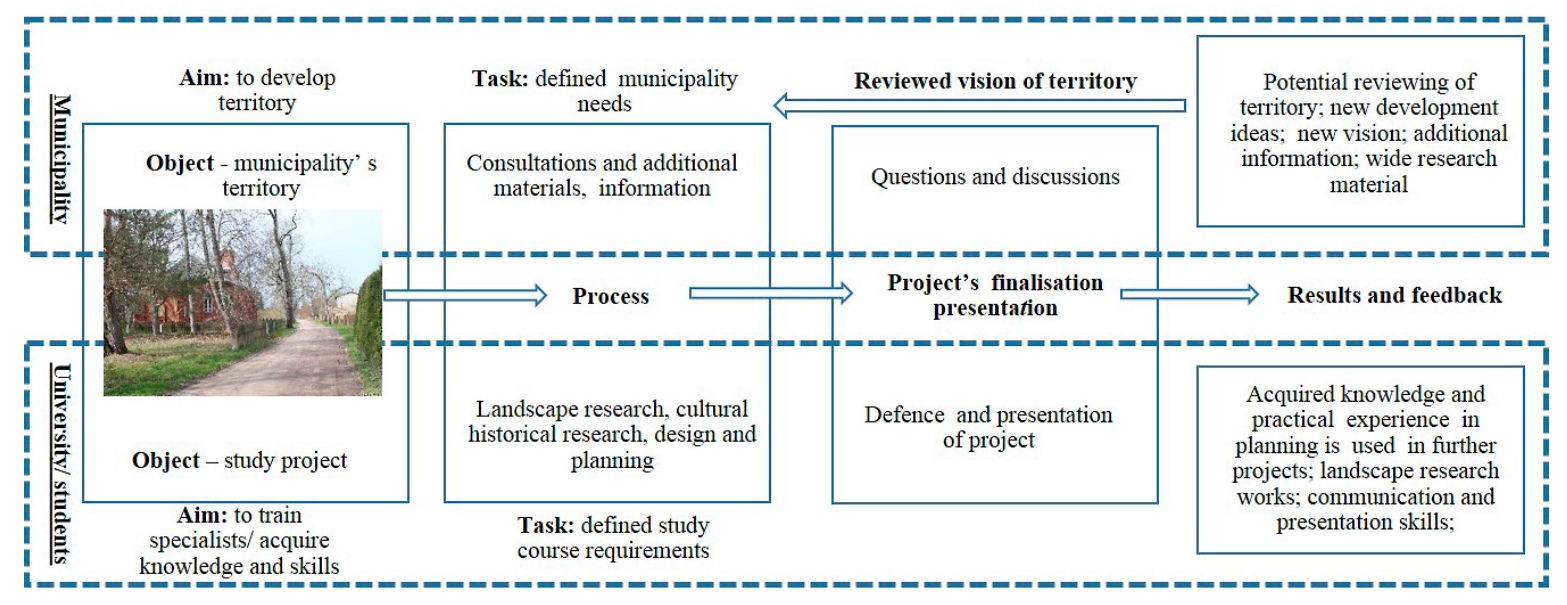

Fig. 2. Trilateral cooperation trough service learning

projects of real territories are designed, in cooperation with the customer prior to developing the diploma thesis the students strengthen the acquired knowledge by having practice in landscape designing companies or local governments.

The model according to which the cooperation between the local governments and faculty/university takes place is schematically shown in Figure 2. On the one side there is the university - the academic staff and students and on the other side - the local government city or municipality council, unions and organisations. This cooperation shall be defined as a horizontal coo- peration, since it is formed between two autonomous organisations.

The aim of the local government is to develop a specific territory through project development in cooperation with the speciality of landscape architecture, while the aim of the study programme and study course is to provide the future specialists with the knowledge and skills required in the specific field (see Latvijas Lauksaimniecibas universitāte 2015). The knowledge and skills are different within each study course, so that the students are able to acquire and strengthen the professional competencies required for each subsequent level or task. 
Most often the faculty/local government cooperation is implemented within the framework of a certain course project. In this case, the local government is the contracting authority, which defines its needs, sets tasks and results to be achieved, providing the necessary cartographic, photographic and other related materials. Taking into account the customer's interests as well as the theoretical knowledge to be strengthened and the competencies to be acquired during the course, the teachers prepare the tasks to be completed by the students in a more detailed way. The tasks can be connected with the research of landscape spatial structure and value, heritage studies, design solutions, planning at different levels of detail and taking into account the specifics of the territory. In the course of 8 weeks ( 1 semester at LUA) the teachers introduced to the students theoretical material related to the type of a specific area and the problem to be solved, such as forming the identity and image of a populated area.

The students have field trips to the territory 1-2 times. During these trips, basing on the previously prepared cartographic material (topographic and other types of maps), they carry out deeper research of the site and make markings on maps. Then, alongside with the acquisition of the theoretical material, the work on the sketch of ideas and the development project of the territory takes place. During the designing period there are several interim reports in which the teachers evaluate the progress of each student or each group, if the work is done in groups. If necessary, the issues which need to be addressed more thoroughly are pointed out. Students are also trained in the techniques of presenting their ideas and communication with the customer, organising discussions in interim reports and working on the design of visual material.

The project's final presentation to the customer is an integral part of service-based learning, because in this way the students have an opportunity to observe how the knowledge acquired during the study course, presentation skills and project execution skills work in practice. Customer's representatives come to the final presentation, participate in discussions, ask questions and comment on the students results. After the final presentation the customer has an opportunity to review the development potential of the territory, find new ideas and obtain a wide range of research material. This is the model according to which service-based learning in landscape architecture is organised at Latvia University of Agriculture. In this research the cooperation within the framework of 18 course projects has been analysed using servicebased learning as well as cooperation with 3 nongovernmental organisations, 8 municipalities and governmental organisations, 4 unions. The analysis was carried out in two stages:

- The evaluation of professional skills and competencies obtained within the specific project from the point of view of the teachers involved.

- Interviewing the representatives of local governments to determine the benefits from the cooperation with the university in the planning of specific territories and to find out the limiting factors.

To evaluate the professional skills and competencies the territories designed within the course projects were grouped according to their size and scale, since it influences the number of the tasks to be done and the degree of the project detailed elaboration (Table 1), consequently also the amount of the knowledge acquired. The interview of the representatives of local governments was carried out in January 2016, using the professional file visidati.lv. The respondents were asked three questions - two multiple choice questions with the possibility to choose several answers and one open question with the possibility to answer in a free style.

\section{Results and discussion}

Evaluating the territory development projects, the teachers involved in them indicated that addressing the territories with an area of up to 5 hectares, the students mainly learn the skills and knowledge of the composition of the territory planning, functional zone, the road network and parking lot development, lighting, greenery and design elements planning, as well as a detailed $3 \mathrm{D}$ visualization development. This can be explained by the high degree of project details elaboration for this planning scale (most often M/S1:200). In some thematic projects the knowledge about specific issues was obtained, such as the location of the territory in the overall structure of the populated area, cultural and historical research, relief and environmental accessibility solutions. Public interviewing skills have been acquired only within the framework of one project, which is explained by the seclusion of the territory and limited public access to most of the designed territories.

The most comprehensive knowledge and professional skills were obtained in the design of the territories with an area of 6 to 30 ha, since the planning scale requires both conceptual and general solutions for M/S1: 500 or M/S1: 1000, as well as a separate place detailing M/S1: 200. Consequently, the knowledge and professional skills gained in the planning of these territories are related to both conceptual solutions of territory development - spatial structure, the common infrastructure of the territory and links with the surrounding landscape, the blue-green networks, visual and physical access, as well as with detailed solutions - 
roads, lighting, greenery, terrain and water and design elements. In the design process of these territories the skills in different approaches to landscape analysis at different scales were obtained. Public interviewing was also used in the designing of these territories so that the students could develop the ability to analyse the needs of the population in the context of landscape architecture technologies.

In the territory group, having an area of over 30 hectares, the students knowledge and professional skills obtained are related to the design of large-scale territories (M/S1:1000, M/S1:10000). These territories are characterized by design tasks and issues more appropriate to large scale. Consequently, the knowledge and professional skills to be acquired are related to the elaboration of the vision of territory de- velopment, planning of spatial structure and the bluegreen networking, infrastructure solutions, in-depth analysis of the landscape, including the research of heritage, ecological, etc. landscapes. In dealing with these territories more knowledge of public interviewing was obtained, since in the developing of such scale projects questionnaires play an important role, because the territory included in the project affects a large part of society. In the planning of these territories, less knowledge and professional skills were obtained relating to the project detail, such as environmental availability solutions, detailed elaboration of greenery, solutions of design elements, etc.

The knowledge and professional skills to be acquired in the project development of territories are summarised in Table 1.

Table 1. The knowledge and professional skills

The knowledge and professional competencies to be acquired about:

\begin{tabular}{|c|c|c|c|c|c|c|c|c|c|c|c|c|c|c|c|}
\hline Territory groups by size & 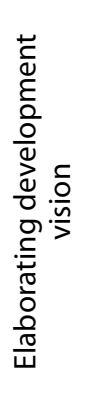 & 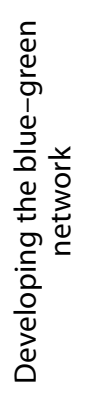 & 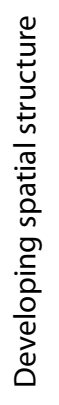 & 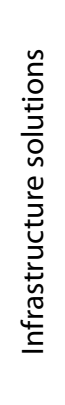 & 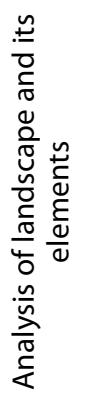 & 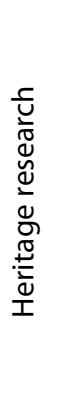 & 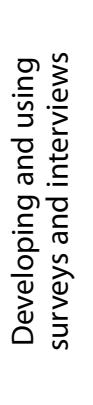 & 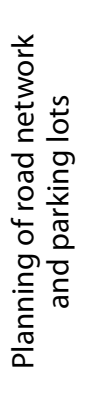 & 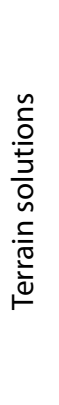 & 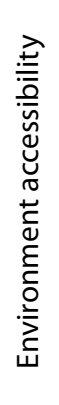 & 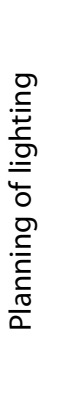 & 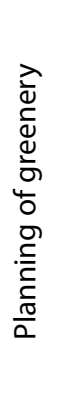 & 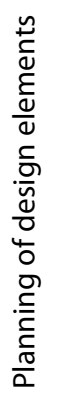 & 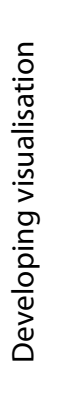 & 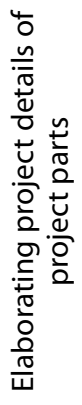 \\
\hline \multicolumn{16}{|c|}{ Territories of up to 5 ha } \\
\hline $\begin{array}{l}\text { State social care centre } \\
\text { „Allaži” (town Allaži) }\end{array}$ & & & & & $\mathrm{x}$ & & & $\mathrm{x}$ & & $\mathrm{X}$ & $x$ & $x$ & $X$ & $\mathrm{X}$ & $\mathrm{X}$ \\
\hline $\begin{array}{l}\text { Šlokenbeka manor } \\
\text { ensemble (town } \\
\text { Milzkalne) }\end{array}$ & & & & & $x$ & $x$ & & $x$ & $x$ & $X$ & $x$ & $x$ & $x$ & $x$ & $\mathrm{x}$ \\
\hline $\begin{array}{l}\text { Courtyard of } 2 \text { Daugava } \\
\text { street in Salaspils city }\end{array}$ & & & & & $\mathrm{x}$ & & & $x$ & & & $x$ & $x$ & $x$ & $x$ & $x$ \\
\hline $\begin{array}{l}\text { Bauska city greenery } \\
\text { territory centre }\end{array}$ & & & & & $\mathrm{x}$ & $x$ & & $x$ & & & & $x$ & $x$ & $x$ & $\mathrm{x}$ \\
\hline $\begin{array}{c}\text { Oskars Kalpaks square } \\
\text { and Strūve park in } \\
\text { Jēkabpils city }\end{array}$ & & & & & $\mathrm{x}$ & $x$ & $\mathrm{x}$ & $\mathrm{x}$ & $x$ & $\mathrm{X}$ & $x$ & $x$ & $\mathrm{X}$ & $x$ & $\mathrm{x}$ \\
\hline $\begin{array}{c}\text { "Raganu park" Krimulda } \\
\text { municipality }\end{array}$ & & & & $x$ & $x$ & $x$ & & $x$ & $x$ & & $x$ & $x$ & $x$ & $x$ & $x$ \\
\hline $\begin{array}{c}\text { Greenery territory } \\
\text { around the vicinity of } \\
\text { Turaida city }\end{array}$ & & & & $x$ & $\mathrm{x}$ & $\mathrm{X}$ & & $\mathrm{x}$ & & & $\mathrm{X}$ & $x$ & $x$ & $x$ & $\mathrm{x}$ \\
\hline \multicolumn{16}{|c|}{ Territories from 6 to 30 ha } \\
\hline $\begin{array}{l}\text { Brukna manor house in } \\
\text { Dāvinu municipality }\end{array}$ & $x$ & & $\mathrm{X}$ & $x$ & $x$ & $\mathrm{X}$ & & $x$ & $\mathrm{x}$ & $X$ & $x$ & $x$ & $x$ & $\mathrm{X}$ & $\mathrm{x}$ \\
\hline Aldaris park in Riga city & $x$ & $x$ & $x$ & $\mathrm{X}$ & $x$ & $x$ & $x$ & $x$ & $x$ & $\mathrm{X}$ & $x$ & $x$ & $x$ & $\mathrm{x}$ & $x$ \\
\hline $\begin{array}{c}\text { Vicinity of Anniņmuiža in } \\
\text { Riga city }\end{array}$ & $x$ & $\mathrm{x}$ & $x$ & $x$ & $\mathrm{x}$ & $x$ & $\mathrm{x}$ & $\mathrm{x}$ & & & & $x$ & & $x$ & \\
\hline
\end{tabular}


The knowledge and professional competencies to be acquired about:

\begin{tabular}{|c|c|c|c|c|c|c|c|c|c|c|c|c|c|c|c|}
\hline Territory groups by size & 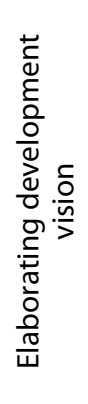 & 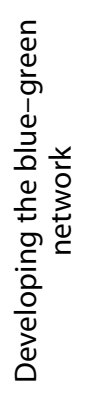 & 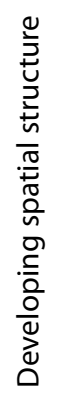 & 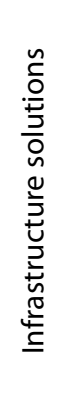 & 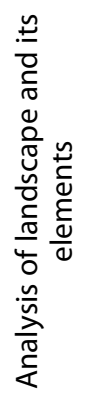 & 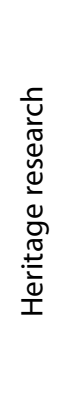 & 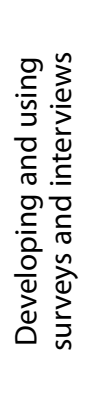 & 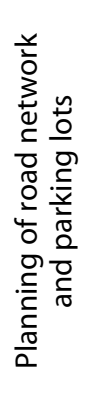 & 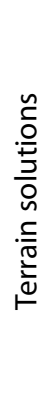 & 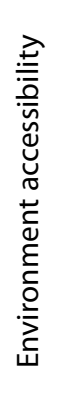 & 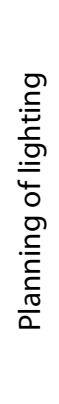 & 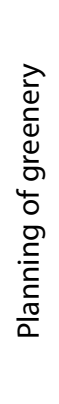 & 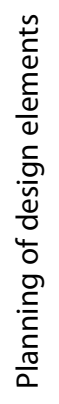 & 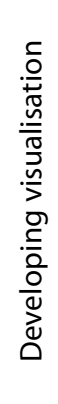 & 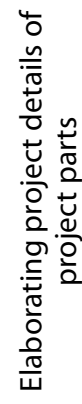 \\
\hline \multicolumn{16}{|c|}{ Territories from 6 to 30 ha } \\
\hline $\begin{array}{l}\text { Ren̦kis garden in } \\
\text { Ventspils city }\end{array}$ & & & $\mathrm{X}$ & & $x$ & $\mathrm{x}$ & & $\mathrm{x}$ & & & $x$ & $x$ & $x$ & $x$ & $\mathrm{x}$ \\
\hline $\begin{array}{l}\text { Sarkanmuiža park in } \\
\text { Ventspils city }\end{array}$ & & & $\mathrm{X}$ & & $\mathrm{X}$ & $x$ & & $\mathrm{X}$ & $\mathrm{X}$ & $x$ & $X$ & $\mathrm{X}$ & $x$ & $\mathrm{X}$ & $\mathrm{X}$ \\
\hline $\begin{array}{l}\text { Swedish rampant in } \\
\text { Ventspils city }\end{array}$ & & & $\mathrm{X}$ & & $\mathrm{X}$ & $x$ & & $x$ & & & $x$ & $\mathrm{X}$ & $x$ & $x$ & $\mathrm{x}$ \\
\hline $\begin{array}{c}\text { Central part of Ranka } \\
\text { village }\end{array}$ & $\mathrm{X}$ & $\mathrm{X}$ & $\mathrm{X}$ & $x$ & $x$ & $x$ & $x$ & $\mathrm{X}$ & & $x$ & $\mathrm{X}$ & $x$ & $x$ & $\mathrm{X}$ & $x$ \\
\hline $\begin{array}{l}\text { Central part of Slampe } \\
\text { village }\end{array}$ & $\mathrm{X}$ & $\mathrm{X}$ & $\mathrm{X}$ & $X$ & $\mathrm{X}$ & $x$ & & $\mathrm{X}$ & & $x$ & $X$ & $\mathrm{X}$ & $x$ & $x$ & $\mathrm{X}$ \\
\hline \multicolumn{16}{|c|}{ Territories over 30 ha } \\
\hline $\begin{array}{c}\text { Coastal nature park, } \\
\text { Saulkrasti town }\end{array}$ & $x$ & $\mathrm{X}$ & $\mathrm{X}$ & $X$ & $X$ & $\mathrm{X}$ & $\mathrm{X}$ & $\mathrm{X}$ & & $\mathrm{X}$ & & & & & \\
\hline $\begin{array}{l}\text { Territory next to Grīva } \\
\text { boulevard in Ogre town }\end{array}$ & $\mathrm{X}$ & $X$ & $X$ & $X$ & $X$ & $X$ & & $X$ & & & & & & & \\
\hline $\begin{array}{l}\text { Jelgava city multi-storey } \\
\text { residential courtyards }\end{array}$ & $X$ & $X$ & $X$ & $X$ & $X$ & $X$ & $X$ & $X$ & & & & & & & \\
\hline
\end{tabular}

Overall, it should be noted that the students within the framework of all the projects acquired knowledge of landscape analysis, the similarities and differences analysing territories of different scales and types. Likewise, the students gained knowledge of the infrastructures of the territories, including planning and organisation of functional zones and road network. Other skills were divided into two blocks. The first block included the skills associated with the large and medium-scale territory planning. They were based more on the ability to conceptually deal with territory development, as well as the link of territories with the surrounding landscape. The second block includes the skills essential for smaller territories whose projects require high detail. Here the knowledge of plant species to be used in greenery emerges, as well as the knowledge regarding the technical solutions of design elements, materials used for road surfaces and elements. Organisation of a public interviewing was primarily used for large-scale territory planning, as it concerned the largest part of the population interested in the results of the project.
Being aware of the knowledge and skills to be acquired in planning territories of different scale and types, it is possible to create a succession of study courses and plan the study process in landscape architecture more accurately. Thus, the knowledge and professional skills acquired during one study course serve as a basis for acquiring the next study course and obtaining new knowledge. Taking this principle into consideration, in LUA landscape architecture studies first knowledge necessary for planning small-scale territories with high detail is acquired, followed by knowledge needed for planning medium and large-scale territories. Within the framework of the research a survey the interview of representatives of local government was carried out to determine the local governments benefits from the cooperation with the faculty as well as the limiting aspects. From 15 representatives, 10 partners or $60 \%$ of them submitted their answers.

Responding to the question: "How do you evaluate the cooperation with the students of landscape architecture of LUA Rural Engineering Faculty, what in your 
opinions are the main benefits from this cooperation?" the representatives of the local governments mentioned firstly - new ideas and seeing things from another point of view (9 responses) (Fig. 3). Local governments often do not have their landscape architect, and the projects of landscape architecture students simultaneously, reflect both the view of a landscape architect and young people, which helps to further develop the ideas about landscape planning, improvement and design. Secondly, with the same number of responses for each of the variants (6 replies) it was acknowledged that the students projects are good teaching materials that can be used for various purposes - to inform the public, and also they are research materials for future development of the territory. Local government representatives noted the students projects as practical materials for the improvement of the territory.

Responding to the second question "What are the limiting aspects of the cooperation with the students of landscape architecture and planning of LUA Rural Engineering Faculty?" the respondents mentioned additional financing necessary for wider cooperation as a limiting factor (4 responses) (Fig. 4). It should be noted that the university should also need additional financing to implement service-learning, providing students with materials and transportation, as well as for the remuneration of teaching staff for the the organization of the work. Respondents also admitted that the regulations of the Republic of Latvia do not allow the students projects officially used as a basis for further work and development. It explains the current form of cooperation, where both the local governments and university operate on a voluntary basis, understanding common interest and benefits. In addition, respondents noted that the deputies of the local governments who are decision-makers, have little awareness of the importance of the sector of landscape architecture and its possibilities of developing a high-quality living environment thus not allowing more actively to develop landscape projects. Therefore, such cooperation is considered to be positive in terms of education for the community. The responses to the third question - "What opportunities do you see for further cooperation with the students and teachers of landscape architecture and planning of LUA Rural Engineering Faculty?" - can be grouped as follows:

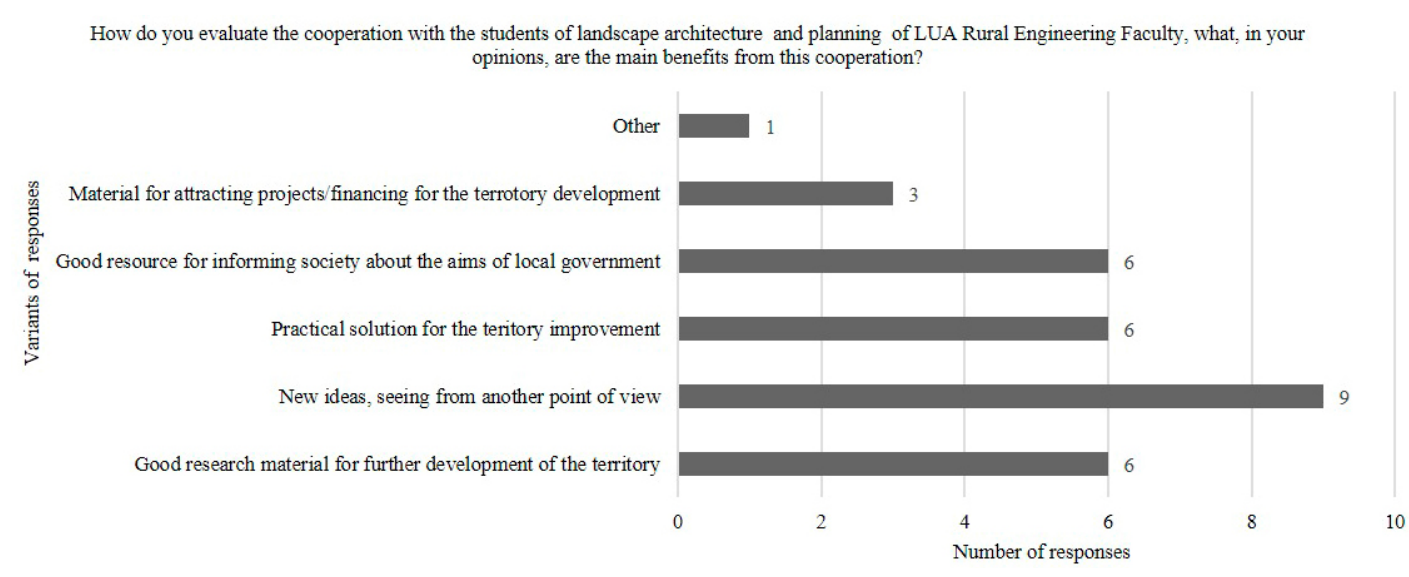

Fig. 3. Survey results about first question

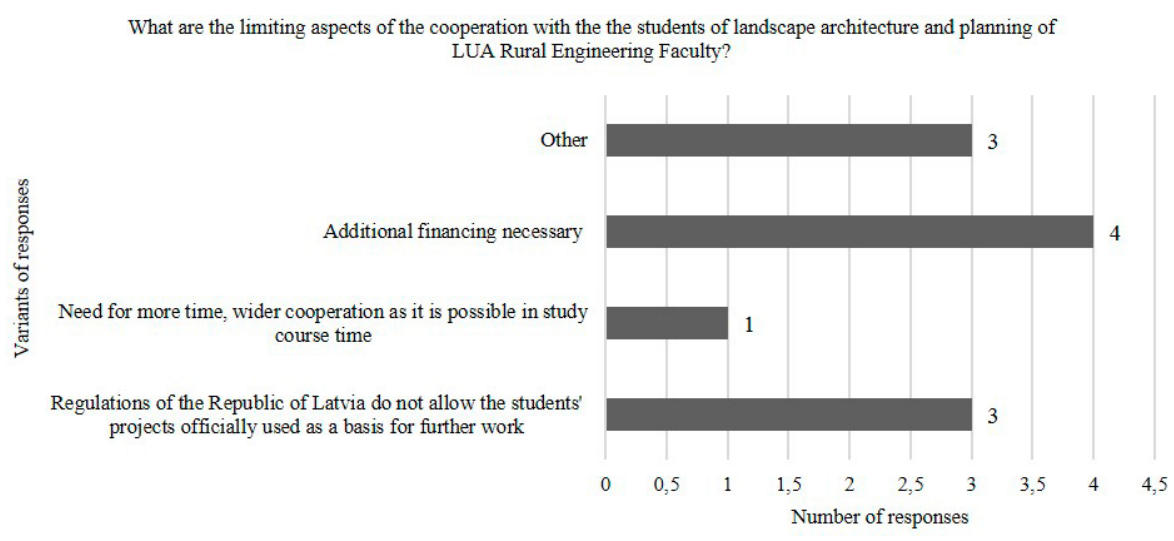

Fig. 4. Survey results about second question 
The desire to continue cooperation, expanding the possibilities and looking at new objects, to cooperate with the university and the teachers also in the scientific field, working together on planning issues.

The desire to co-participate in the students acquisition of knowledge, offering the opportunities for practising and working on project implementation, consultation and active participation. All respondents were satisfied with the cooperation and they look forward to further development of cooperation. In addition to the students acquired professional skills and local territory development solutions available to the local governments, both the university and the local governments of these projects got positive publicity in local newspapers and on websites of the local government and university. Thus, the importance and possibilities of landscape architecture are popularised and also the importance and desire to improve people's quality of life environment are promoted.

\section{Conclusions}

Evaluating the global experience of university and local government cooperation, it can be concluded that it is implemented differently in different countries - ranging from formal cooperation to strategies developed at a national level.

In scientific research papers it is noted that in any of the forms of cooperation, it is effective and brings benefits to both parties. Currently, in Latvian, this cooperation takes place on a voluntary basis, based on the needs of both parties. However, the principle of voluntarism has not diminished the interest of students and their sense of responsibility, working on real projects with real customers.

Analysing the projects developed within the framework of cooperation, it has been concluded that from the university's point of view, the greatest benefit from cooperation with the local governments is the opportunity to keep up with current territory planning-related problems and needs of the local governments. Thus, it is possible to adapt the study process and materials to a successful resolution.

According to the results of the cooperation partners' interviews it can be concluded that such cooperation is important and necessary. The benefits the students gained were that they got acquainted with the specifics of the work of landscape architect and the skills the profession requires, including not only technical and theoretical knowledge, but also communication, presentation and interpersonal skills. For students such cooperation enriches their work experience on their CVs, especially if the local governments issue a certificate of the student's work on a particular project. The benefit the local governments had from such cooperation is the theoretical substantiation necessary for decision making, as well as the data obtained from the design research part, which serve as the basis for other forms of development plans for specific territories. Likewise, the local governments have the possibility to obtain several scenarios of development, not only for the development of the territory itself, but also for linking it with the surrounding territory.

In the interviews of the representatives of local governments, the Latvian regulations stipulating the order in which territory planning should be carried out, were mentioned as limiting conditions. Consequently, the projects developed by students and mentored by teachers can serve only as sketches of ideas or concepts rather than an official work material which can be immediately implemented. Similarly, the regulations limit the students participation in competitions and design procurement announced by the local governments. For developing mutually beneficial cooperation the local government and the university would need to develop a common strategy and vision, where the aims and tasks to be reached by both parties are included and the principles of co-participation of each party to implement them are formulated.

\section{References}

Amstrong, H. 1999. Design studios as research: an emerging paradigm for landscape architecture, Landscape Review 5(2): 5-25.

Angotti, T.; Doble, C.; Horrigan, P. 2012. Service-learning in design and planning: educating at the boundaries. New Village Press.

Augstskolu likums. 1995. [online], [cited January 2015]. Available from Internet: http://likumi.lv/doc.php?id = 37967

Baum, H. 1997. Teaching practice, Journal of Planning Education and Research 17: 21-29. http://dx.doi.org/10.1177/0739456X9701700103

Benson, B. J.; Mackenzie, M. D. 1995. Effects of sensor spatialresolution on landscape structure parameters, Landscape Ecology 10(2): 113-120. http://dx.doi.org/10.1007/BF00153828

Bloemers, T. 2010. Landscape in a changing world: bridging divides, integrating disciplines, serving society, Science Policy Briefing 41(October 2010). European Science Foundation.

Burton, M. 2015. How was your work experience? Students' perspectives of the year in practice, in ECLAS conference, 21-24 September 2015, Tartu, Estonia.

Chinowsky, P. S.; Brown, H.; Szajnman, A.; Realph, A. 2006. Developing knowledge landscapes through project-based learning, Journal of Professional Issues in Engineering Education and Practice 132(2): 118-124. http://dx.doi. org/10.1061/(ASCE)1052-3928(2006)132:2(118)

City of Linköping. 2014. Strategy for cooperation with universities and colleges [online], [cited January 2015]. Available from Internet: http://www.linkoping.se/Global/Om\%20 kommunen/Utveckling\%20och\%20samverkan/strate- 
giska\%20universitetskontakter/Strategi\%20samverkan univ13_eng.pdf? epslanguage $=\mathrm{sv}$

Deming, M. E.; Swaffield, S. 2011. Landscape architectural research: inquiry, strategy, design. John Wiley \& Sons, 272.

Forsyth, A.; Lu, H.; McGirr, P. 2000. Service learning in an urban context: implications for planning and design education, Journal of Architectural and Planning Research 17(3): 236-260.

Freestone, R.; Thompson, S.; Williams, P. 2006. Student experiences of work-based learning in planning education, Journal of Planning Education and Research 26(2): 237-249. http://dx.doi.org/10.1177/0739456X06295027

Genca, M. 2015. The project-based learning approach in environmental education, International Research in Geographical and Environmental Education 24(2). http://dx.doi.org/10.1080/10382046.2014.993169

Grabbatina, B.; Fickeya, A. 2012. Service-learning: critical traditions and geographic pedagogy, Journal of Geography 111(6): 254-260. http://dx.doi.org/10.1080/00221341.2012.694465

Grandin, J.; Apine, L.; Kovbasko, O.; Zhuk, Y. 2010. Student's role in sustainable development: to create attractive and sustainable future, in M. Kḷavinš , W. L. Filho, J. Zalıoksnis (Eds.). Environment and sustainable development. University of Latvia, Riga.

Healey, P. 1997. Collaborative planning: shaping places in fragmented societies. UBC Press, 338.

Heckley, S.; Cre, I; Da Cunha Ferreira A. A. P.; Guehnemann A.; Marsden, G.; May, T.; Mullen. C. 2014. Why is Cooperation a challenge in sustainable urban mobility planning? [online], [cited March 2014]. West Yorkshire Passenger Transport Executive, POLIS, Institute for Transport Studies; University of Leeds. Available from Internet: http://www. eltis.org/sites/eltis/files/trainingmaterials/challenge_cooperation_final.pdf

Horizon 2020 and ERA. 2014. Strategy for research and innovation cooperation with the EU [online], [cited January 2015. Norwegian ministry of education and research. Available from Internet: https://www.regjeringen.no/contentassets/4c96155c 697f47cabc2c4ea23e0507ec/strategy-for-research-and-innovation-cooperation-with-the-eu-horizon-2020-and-era.pdf

Latvijas Lauksaimniecības universitāte. 2015. Latvijas Lauksaimniecības universitātes attīstības stratēgija 2015.-2020. gadam [online], [cited 9 December 2013]. Available from Internet: http://www.llu.lv/sites/default/files/2016-06/ strat\%C4\%93\%C4\%A3ija_gara_saturs_logotips.pdf

Marcia, L. 2008. Nation. Project-based learning for sustainable development, Journal of Geography 107(3).

Nelsona, C.; Antayá-Mooreb, D.; Badleyc, K.; Colemand, W. 2010. The sustaining possibilities of service-learning engagements, Teachers and Teaching: theory and practice. Sustaining Teachers in Teaching 16(3): 353-371. http://dx.doi.org/10.1080/13540601003634529

Oles, T.; Horrigan, P. 2015. Learning to land, landing to learn - on fieldwork in landscape architecture education, in ECLAS conference, 21-24 September 2015, Tartu, Estonia.

Postma, J. 2013. The ability to work together: municipal cooperation for effective social sector policy implementation [online], [cited July 2015]. Available from Internet: http://essay. utwente.nl/63657/

Saura, S.; Martínez-Millán, J. 2001. Sensitivity of landscape pattern metrics to map spatial extent, Photogrammetric Engineering \& Remote Sensing 67(9): 1027-1036.

Silinevica, I. 2015. The role of collaboration municipality - regional university in sustainable tourism development: case study of Dagda county, in 10th International Scientific and Practical Conference, 2015, Rezekne, Latvia.

http://dx.doi.org/10.17770/etr2015vol2.266

Varna municipality. 2015. Municipal Strategy for cooperation with the institutions of higher education and consolidation of Varna as an international university city [online], [cited September 2015]. Available from Internet: http://www.google.lv/url?sa $=$ t\&rct $=\mathrm{j} \& \mathrm{q}=$ \&esrc $=\mathrm{s} \&$ source $=$ web\&cd $=$ $2 \& v e d=0$ ahUKEwjAhYmQvpfKAhXKiywKHRWBoQFggiMAE\&url = http\%3A\%2F\%2Furbact.eu\%2Ffile \%2F11199\%2Fdownload\%3Ftoken\%3D8TyDC0pA\&usg = AFQjCNHGp4I-4NbzXKLQcZuJouVBWcSy5A

Wenger-Trayner, E.; Mark Fenton-O'Creevy, M.; Hutchinson, S.; Kubiak, C.; Wenger-Trayner. B. 2014. Learning in landscapes of practice: boundaries, identity, and knowledgeability in practice-based learning. Routledge, 182.

Williams, P.; Freestone, R.; Thompson, S. 2007. Measuring the effectiveness of practice-based learning: monitoring student perceptions of work experience, in Built Environment Education Conference, 12-13 September 2007, Central London.

Wu, J. G. 2004. Effects of changing scale on landscape pattern analysis: scaling relations, Landscape Ecology 19(2): 125-138.

Wu, J. G.; Shen, W. J.; Sun, W. Z. 2002. Empirical patterns of the effects of changing scale on landscape metrics, Landscape Ecology 17(8): 761-782.

Zadek, S.; Forstater, M.; Naidoo, S. 2012. Shaping a Sustainable Future [online], [cited July, 2012]. Available from Internet: http://www.un.org/en/ecosoc/newfunct/pdf/dcf_australia_zadek_may_2012.pdf

Zemgales Ziṇas. 2013. Topošie LLU ainavu arhitekti palìdz sapost Liktendārzu [online], [cited November 2013]. Available from Internet: http://zz.diena.lv/vietejas-zinas/jelgava/toposie-llu-ainavu-arhitekti-palidz-sapost-liktendarzu-169808

\section{NATALIJA N̦ITAVSKA}

Dr of Architecture, Associated Professor at the Landscape architecture and planning Department of the Latvian University of Agriculture. Field of research: coastal landscape, landscape identity, Baltic sea, teaching methods in landscape architecture field.

\section{DAIGA ZIGMUNDE}

Dr of Architecture, Professor at the Landscape architecture and planning Department of the Latvian University of Agriculture. Field of research: ecological and esthetical aspects in landscape, ecological design, landscape research methods, teaching methods in landscape architecture field.

\section{MADARA MARKOVA}

Dr of Architecture, Assistant Professor at the Landscape architecture and planning Department of the Latvian University of Agriculture. Field of research: sacral landscape, cultural landscape and it's elements, teaching methods in landscape architecture field.

\section{UNA İLE}

Dr of Architecture, Assistant Professor at the Landscape architecture and planning Department of the Latvian University of Agriculture. Field of research: urban planning and design, public spaces, aesthetic quality in multi-storey residential courtyards. 